\title{
Taalseksisme as 'n vorm van eensydige leksikografie
}

\author{
A.A. Beyleveld en G.J. van Jaarsveld, Departement Afrikaans en \\ Nederlands, Universiteit van die Oranje-Vrystaat
}

\begin{abstract}
Language Sexism as a Form of Biased Lexicography. As an interface between linguistics and society, the dictionary serves to open up linguistics to language users in a very special way. A pragmatic approach, however, is also expected from the lexicographer, in the sense that the guidance provided in a dictionary should reflect actual language usage. A dictionary therefore has both a normative and informative character. Add to this the fact that dictionaries are used as authoritative works of reference, and the possibility that they serve to reinforce and to maintain specific language patterns is not excluded. In a period characterized by an increased focus on the prejudiced categorizing of women, the dictionary, as a source of cultural authority, is also under suspicion. The possibility that dictionaries may contribute to stereotyped roles and sexist suppositions by means of biased lexicographic practices, is discussed in this article. Words under the letter $M$ in both a bilingual and an explanatory dictionary were studied in order to determine whether these lexicographic works are indeed guilty of linguistic sexism.
\end{abstract}

Keywords: DICTIONARY AS INTERFACE BETWEEN LINGUISTICS AND SOCIETY, LANGUAGE SEXISM, BIASED LEXICOGRAPHY, USER-GUIDANCE, CULTURAL AUTHORITY OF DICTIONARIES

Opsomming: As hussenganger tussen die taalkunde en die maatskappy bring die woordeboek die taalkunde op ' $n$ besondere wyse by die taalgebnilker uit. Hierbenewens word daar egter ook 'n pragmatiese benadering van die leksikograaf verwag, in dié sin dat die leiding wat die woordeboek gee 'n weerspieëling moet wees van werklike taalgebruik. Woordeboeke beskik dus in ' $n$ sekere sin oor beide ' $n$ normatiewe en ' $n$ informatiewe karakter. Voeg hierby die feit dat woordeboeke as gesaghebbende naslaanbronne gebruik word, en die moontlikheid dat dit bydra tot die versterking en behoud van bepaalde taalpatrone is nie uitgesluit nie. In ' $n$ tyd waarin daar toenemend aandag gegee word aan die bevooroordeelde kategorisering van die vrou, staan die woordeboek as kulturele gesagsbron ook onder verdenking. Die moontlikheid dat woordeboeke deur middel van eensydige leksikografie kan bydra tot stereotiepe roltoewysings en seksistiese aannames word in hierdie artikel bespreek. Woorde onder die letter $M$ is in sowel ' $n$ tweetalige as verklarende woordeboek nagegaan om te bepaal of dié woordeboeke hulle inderdaad aan taalseksisme skuldig maak.

Sleutelwoorde: WOORDEBOEK AS TUSSENGANGER TUSSEN TAALKUNDE EN MAATSKAPPY, TAALSEKSISME, EENSYDIGE LEKSIKOGRAFIE, GEBRUIKSLEIDING, KULTURELE GESAG VAN WOORDEBOEKE 


\section{Inleiding}

Geslag, net soos ras, is 'n sosiale probleemarea vanweë die feit dat oorheersing dikwels op grond van onderskeid geregverdig word. Dienooreenkomstig word seksisme deur 'n vooraanstaande leksikograaf soos Hauptfleisch (1989) uitgesonder as 'n gebied wat vanuit 'n sosiolinguistiese oogpunt as leksikografies sensitief beskou kan word.

Met die term seksisme word daar verwys na die vergestalting van 'n bevooroordeelde siening van die geslagte. Dié siening berus op 'n aanname dat die een geslag vanweë ' $n$ meerderwaardige samestelling daarop geregtig is om die ander geslag te oorheers (vgl. onder andere Grobler 1983). Anders gestel: seksisme bestaan daarin dat stereotiepe roltoewysings wat 'n impak op die lewenswyse van mense het, op die basis van geslag geskied; dat ondergeskikte, passiewe rolle gewoonlik aan die vroulike geslag toegewys word op veral die intellektuele en ekonomiese terreine van die samelewing.

Taalseksisme wat onderskei moet word van die verskillende spraakpatrone van mans en vroue wat deur verskeie navorsers toegeskryf word aan die sosialiseringsproses (vgl. Trudgill 1978; Maltz en Borker in Coates en Cameron 1988), kan in die woorde van Adey, Orr en Swemmer (1989: 226) soos volg gedefinieer word:

"Sexist language is language that conveys, through linguistic means such as use of the word 'mankind', 'he' as the generic pronoun, and condescending nomenclature to refer to women, stereotyped and biased views of the human race, and of the role of women in society."

Die feit dat vroue se sosiale agterstande in die moderne samelewing nie langer aan diskriminerende praktyke (of dan ten minste in dieselfde mate as vroeër) toegeskryf kan word nie (vgl. byvoorbeeld salarispariteit op vele beroepsterreine, vroue se regsbevoegdheid en ook hulle toetrede tot tradisioneel manlike ampsposisies en beroepe), het die rol van taal in die maatskaplike devaluasie van die vrou opnuut op die voorgrond gedwing (vgl. in dié verband die bydraes van onder andere Thome en Henley 1975; Spender 1980; Coates en Cameron 1989).

Kernurae wat na vore kom wanneer die verband tussen taal en die mens se werklikheidsbelewing sosiolinguisties in oënskou geneem word, is die volgende:

Dien taal as sosialiseringskrag wat daartoe bydra om bepaalde geslagsrolle te konseptualiseer en in stand te hou?

Is taal bloot ' $n$ weerspieëling van bepaalde gemeenskapsnorme wat sorg vir die onderskeid tussen die twee geslagte? (Die implikasie synde dat taal ook verandering in die sosiale orde sal weerspieël.) 
Sommige vooraanstaande linguiste (vgl. Thome, Kramarae en Henley 1983) is van mening dat hierdie vrae van nuuts af teen die agtergrond van die SapirWhorf-hipotese ondersoek behoort te word.

\section{Sapir-Whorf-hipotese}

In die ekstreme weergawe kom die Whorfiaanse teorie, wat aan die opvattinge van taalkundiges soos Edward Sapir (1884-1939) en Benjamin Lee Whorf (1897-1941) geknoop word, daarop neer dat die verhouding tussen taal en denke kousaal is. Webb (1989: 133) stel dit só: "... die linguisties gedefinieerde konseptuele kategorieë van 'n taal het 'n beherende en beperkende effek op kognitiewe denke."

Alhoewel die ekstreem deterministiese weergawe van die Sapir-Whorfhipotese grootliks in onguns verval het, onder andere vanweë die feit dat dié teorie twee- en meertaligheid in gedrang bring (vgl. Lyons 1981: 305), is die studie van die verhouding tussen taal, denke en kultuur in terme van die swakker weergawe van die Whorfiaanse teorie tans weer aanvaarbaar. Die bydrae van die vrouebevrydingsbeweging sedert die vroeë sestigerjare moet in dié verband nie gering geskat word nie.

Volgens die swakker, relatiwistiese Whorfiaanse teorie is die mens se taal en sy belewenis van die werklikheid altyd naas mekaar te stel, met taal as die "manipulerende en aktiverende krag in die simbiotiese verhouding" (Esterhuyse 1986: 33). Whorf self was egter nie baie begaan oor wat eerste was in terme van taalpatrone en kulturele norme nie. Hy was tevrede om tot die slotsom te kom dat "... in the main they have grown together, constantly influencing each other" (Allen en Pit Corder 1973: 124). Die moontlikheid bestaan dus, volgens Whorf, dat taal enersyds die interaktiewe weerspieëling van 'n bepaalde kultuurgroep se norme kan wees, en andersyds 'n vormende invloed op die kultuur uitoefen juis omdat dit aan die werklikheid gestalte gee.

In ooreenstemming hiermee is die doel van hierdie ondersoek nie om uitsluitsel te gee oor die vraag of die woordeboek 'n seksistiese samelewing weerspieël, en of dit instrumenteel is in die instandhouding daarvan nie. Na analogie van Gershuny (1974) se ondersoek na seksistiese taalgebruik in die Random House Dictionary en dié van De Roo (1990) in Van Dale, word daar bloot gepoog om die hantering van seksisme in Afrikaanse woordeboeke op 'n eksemplariese wyse na te gaan en te rapporteer.

\section{Taalseksisme en die woordeboek}

Die leksikograaf word veelal beskou as die tussenganger tussen linguistiek en die maatskappy. Een van die woordeboek se primêre take is om die gebruiker ingelig te hou omtrent verandering wat in die taal plaasvind. In dieselfde asem word daar egter gesê dat woordeboeke te dikwels vassteek by konvensionele 
taalgebruik en nie tred hou met verandering nie (vgl. Gouws 1985: 4).

In 1934 al het Mansion (soos aangehaal deur Al-Kasimi 1983: 3) gesê: "... the mind of the lexicographer seems invariably to be anchored in the past ..." Alhoewel sy bedoeling gemik was op die feit dat die leksikografie daarvoor bekend is dat dit nie juis tred hou met ontwikkeling op die gebied van linguistiese teorievorming nie, maar dat dit eerder toegee aan die eise van die praktyk, kan dit net so goed van toepassing gemaak word op leksikografiese onsensitiwiteit vir woorde, uitdrukkings, leksikale definisies en gebruiksleiding wat as seksisties bestempel kan word. Vanweë hierdie feit kan dit wees dat ' $n$ gemeenskap al 'n bepaalde sensitiwiteit vir diskriminerende praktyke (soos inderdaad die geval is met die bevordering van gelykheid tussen vroue en mans) ontwikkel het, maar dat tradisioneel gevestigde vorme, gebruike en betekenisinhoude hardnekkig in woordeboeke bly voortleef.

Die ironie is dat die gesag van 'n woordeboek bo verdenking staan en dat woordeboeke as sodanig 'n wetgewende karakter verkry het. Morris Bishop (soos aangehaal deur Gershuny 1974: 159) het hom al in 1969 só daaroor uitgelaat: "One of our commonest phrases is 'look it up in the dictionary'. (Not any particular dictionary; just the dictionary). Every court of law has its big dictionary; the law settles cases, awards millions, rates crimes and misdemeanors, by quoting the definitions of some poor attic lexicographer, a harmless drudge." Gouws (1989: 13-14) verwys na 'n pragtige geval waar 'n hofuitspraak in Suid-Afrika berus het op die WAT se inskrywings fotografie en fotografies. Wat meer is, die taalgebruiker het mettertyd so gesus geraak deur die behoudendheid van woordeboeke, dat 'n uitsondering op die reël openbare misnoeë ontketen. Vergelyk hier die kritiek wat Webster's Third New International Dictionary ontvang het vanweë die feit dat erkenning gegee is aan gewone gebruikswoorde soos "ain't" en "finalize" (Gouws 1985: 5).

Dat die publiek die woordeboek se rol as voorskrywer eerder as beskrywer van betekenis en gebruik baie hoog aanslaan, is duidelik. Hiermee wil daar nie te kenne gegee word dat die woordeboek ook voorskriftelik is met betrekking tot die sosialisering van manlike en vroulike tipes nie, maar wel dat die woorde en uitdrukkings waarmee manlike en vroulike rolle in 'n woordeboek geassosieer word, geklee is in "... an authenticity, authority, and stability that is only rivaled by the Bible..." (Gershuny 1974: 160).

Indien die gesaghebbendheid van die woordeboek vertolk word as ' $n$ tasbare bewys van die geloof wat die mens in die bestaande taalkategorieë het, het dit seker tyd geword om die woordeboek as kulturele gesagsbron onder die loep te neem.

\section{Eensydige leksikografie?}

Die vraag mag moontlik ontstaan of 'n eensydige weergawe van die werklikheid hoegenaamd in dieselfde asem as leksikografie genoem moet word. Daar word immers na leksikograwe verwys as objektiewe en gewetensgetroue 
optekenaars en verklaarders van die taalskat in al sy vorme en fasette (vgl. Hauptfleisch 1989). In antwoord hierop kan daar verwys word na Claus Mueller se ondersoek na inskrywings in Duitse woordeboeke vóór en ná die Tweede Wêreldoorlog. Esterhuyse (1986) toon aan dat Mueller bewys het dat woordeboeke ideologies gelaai kan word. Eensydigheid, oftewel 'n subjektiewe optekening van die taalskat kan, volgens Esterhuyse (1986), bewerkstellig word deur 'n ongebalanseerde hantering van 'n aantal leksikografiese take. Twee van hierdie take, naamlik die wyse waarop woorde/uitdrukkings omskryf word en die hantering van voorbeeldsinne, het betrekking op hierdie ondersoek.

Met hierdie ondersoek word beoog om vas te stel of woordeboekmakers 'n leksikografiese eensydigheid in hul hantering van die Afrikaanse woordeskat openbaar ten opsigte van die twee take hierbo genoem, met die semantiese versmoring van vroue en gebruiksleiding wat die vrou onsigbaar maak, as invalshoek. As hipotese geld dat woordeboeke een van die vernaamste voorraadskure en versterkers van 'n samelewing se vooroordele is.

Twee woordeboeke is vir die doel van die ondersoek op 'n eksemplariese wyse onder die vergrootglas geplaas, naamlik: Verklarende Afrikaanse Woordeboek (Kritzinger en Labuschagne 1982) en die Tweetalige Woordeboek/Bilingual Dictionary (Bosman, Van der Merwe en Hiemstra 1984).

Die navorsingsvrae waaromheen die empiriese ondersoek geloods is, is die volgende:

Is stereotipering van en vooroordele jeens die vrou inderdaad in die twee gemelde leksikografiese werke aanwesig?

Indien wel, in watter mate word dit deur middel van betekenis- en gebruiksleiding gekommunikeer?

\section{Gebruiksleiding in die Tweetalige Woordeboek}

Vanweë die toename in internasionale interaksie en samewerking het die tweetalige woordeboek onherroeplik deel geword van die mensdom se daaglikse ekonomiese, intellektuele en kulturele aktiwiteite, en dan wel in die sin van 'n praktiese gereedskapstuk. Gevolglik is daar in soverre dit die Tweetalige Woordeboek/Bilingual Dictionary (1984) betref, gekonsentreer op gebruiksleiding.

Die meeste potensiële woordeboekkopers is pragmaties in hul benadering tot leksikale naslaanwerke. Hulle benutting van die woordeboek is gerig op korrekte gebruik en derhalwe is goeie gebruiksleiding baie belangrik (vgl. Gouws 1984: 4). Wanneer 'n woordeboekmaker dus 'n leksikale definisie opstel, kan hy nie slegs 'n abstraksie van die betekenis formuleer op grond van sy waarneming nie - daar moet ook leiding gegee word t.o.v. die verskillende kontekste waarbinne 'n bepaalde woord gebruik kan word. Voorts moet 
gebruiksgevalle uit sowel skriftelike as gesproke taalgebruik opgeteken word. Aldus Eksteen (1967).

Deur ondersoek in te stel na die voorkomsfrekwensie van die manlike (hy/sy) en vroulike (sy/haar) voomaamwoorde in gebruiksvoorbeelde, sou ' $n$ mens dus ' $n$ sosiale patroon t.o.v. mans en vroue se "sigbaarheid" in geskrewe bronne, die media en die werklike lewe kan blootlê. Indien daar voorts van die veronderstelling uitgegaan word dat die leksikograaf op grond van 'n professionele verantwoordelikheid, objektiwiteit en integriteit nie sal toelaat dat persoonlike voor- of afkeure sy optekening van die taalskat beïnvloed nie, sou ' $n$ mens sekerlik kon verwag dat manlike en vroulike woorde op 'n gelykwaardige basis in voorbeeldsinne aangetref sou word.

Voorbeeldsinne van al die lemmas onder die letter $\mathbf{M}$ is vir die doel van die ondersoek ontleed. In totaal is 223 sinne wat t.o.v. 68 inskrywings aangegee is, ontleed. Daar is getel hoeveel keer (dit wil sê in hoeveel voorbeeldsinne) manlike, en hoeveel keer vroulike selfstandige naamwoorde en voomaamwoorde gebruik is. Die voorkomsfrekwensie word as 'n persentasie uitgedruk (Tabel 1).

Tabel 1

Distribusie van geslagsaanwysing in voorbeeldsinne onder die letter $M$ in Tweetalige Woordeboek/Bilingual Dictionary

$\begin{array}{lcr}\text { Geslag } & \text { Aantal woorde } & \% \\ \text { Vroulik } & 15 & 7 \\ \text { Manlik } & 208 & 93 \\ \text { TOTAAL } & 223 & 100\end{array}$

In die geheel gesien vergelyk die voorkoms van vroulike woorde in voorbeeldsinne baie ongunstig met dié van manlike woorde: die ratio is ongeveer $1: 14$, wat ' $n$ aanduiding is van die mate waarin die vroulike geslag linguisties "onsigbaar" gemaak word.

In gevalle waar vroulike woorde wel in voorbeeldsinne voorkom, is die klem wat op liggaamlikheid val, in 3 van die 15 voorbeelde, opvallend:

"Sy het 'n vel so wit as melk"

"Sy het 'n dun middeltjie"

"Sy is nie op haar mondjie geval nie"

Alhoewel die ondersoek nie daarop gemik is om die Sapir-Whorf-hipotese waar of vals te bewys nie, is dit nietemin interessant om die resultate ook teen hierdie agtergrond te interpreteer. Volgens die Sapir-Whorf-hipotese dra woorde in hulle hoedanigheid as klassifiseerders by tot die proses van konsep- 
tualisering van die werklikheid. Met ander woorde, woorde wat in die konteks van ' $n$ strukturele eenheid in dieselfde klas as ' $n$ manlike of vroulike woord val, dra daartoe by dat ' $n$ sekere woord met 'n sekere geslag geassosieer' word (Gershuny 1974). ' $n$ Paar voorbeeldsinne kan dien om te illustreer hoe manlike en vroulike woorde konseptueel met positiewe of negatiewe attribute in verband gebring word:

"'n Monster van 'n vrou"

"Hy is sy vak heeltemal magtig"

"Hy het sy gehoor meegesleep"

"Hy is my meerdere"

Stereotiepe roltoewysing spreek ook uit die volgende voorbeeldsinne:

"Beroemde manne"

"Sy is mal oor hom"

"n Staatsman moet sy volk meevoer"

Gebruiksleiding in hierdie trant het tot gevolg dat stereotiepe semantiese assosiasies met manlike en vroulike woorde versterk word en sodoende word 'n definitiewe bydrae gemaak tot die kulturele konsepte wat rondom die geslagte bestaan.

\section{Betekenisleiding in die eentalige, verklarende woordeboek}

Volgens Gouws (1985: 3) het navorsing getoon dat betekenisleiding die gebruikers van eentalige woordeboeke se primêre behoefte is. Gevolglik is daar t.o.v. die Verklarende Afrikaanse Woordeboek (1982) gekonsentreer op die semantiese funksie.

Eksteen (1967: 17) wys daarop dat die grondbeginsel van verklarende leksikografie daarin setel dat die woordeskat in 'n woordeboek 'n weergawe moet wees van die gebruik van 'n taalgemeenskap. Verandering wat in die taal plaasvind, moet dus ook in woordeboeke gereflekteer word. In dié verband meen Grobler (1985: 1) dat die meeste tale se leksikons voortdurend groei, maar dat daar in één opsig nie op dinamiese vooruitgang aanspraak gemaak kan word nie - en dít is op die semantiese terrein, wat verband hou met manlike en vroulike kategorisering.

Betekenisoordrag in ' $n$ woordeboek geskied veral d.m.v. definisies (of "definiens", vlg. Gouws 1989: 39 se fyner onderskeid). Volgens Eksteen (1967: 12) verskil die leksikale definisie van enige ander soort definisie in dié sin dat dit uit ' $n$ bepaalde taalwerklikheid geabstraheer word: ' $n$ mens kom ' $n$ woord teë, vra na die betekenis daarvan, en dié betekenis word dan gedefinieer met behulp van gegewens wat berus op die gebruik van die woord deur taalge- 
bruikers binne $n$ bepaalde taalgemeenskap. In hierdie $\sin$ is woordeboekdefinisies ' $n$ weerspieëling van die kulturele werklikheid van ' $n$ bepaalde gemeenskap.

Ten einde vas te stel of die leksikograwe van die Verklarende Afrikaanse Woordeboek (1982) betekenismatig skuldig is aan 'n stereotiepe kategorisering van geslagsrolle, is die letter $\mathbf{M}$ se inskrywings krities ontleed. Die keuse vir ontleding het spesifiek op $\mathbf{M}$ geval, aangesien dit komposita met man-, mansen manne- as bepalers insluit, wat alreeds 'n mate van kategorisering veronderstel. 'n Lys van woorde wat spesifiek (+MANLIK) of (+VROULIK) gemerk is, is gemaak en dié woorde se semantiese kenmerke is d.m.v. komponentanalise beskryf. Verder is daar in die besonder onder die letter $\mathbf{M}$, maar ook in die algemeen, opgelet na betekenisbeskrywing waardeur die manlike geslag verhef of die vroulike geslag verkleineer word. Daar is ook in die besonder aandag gegee aan betekenisleiding wat stereotiepe houdings en verwagtings t.o.v. die twee geslagte weerspieël.

Volgens die teorie van komponentanalise kan 'n woord in betekeniskomponente onderverdeel word op só 'n wyse dat die eindproduk die volledige reeks betekenisatome van die woord blootlê sonder om iets meer as die betekenis aan te bied: "Semantic components (or features) are theoretical constructs which can characterize the vocabulary of a language; each lexical item will be defined in terms of the components. In a sense, a dictionary definition is an informal componential.analysis, in which each part of the definition is a component" (Lehrer soos aangehaal in Gouws 1985: 13).

Deur van komponentanalise gebruik te maak, word daar gepoog om in 'n geskematiseerde vorm die denkprosesse weer te gee wat baie vinnig en op 'n nie-waarneembare basis by die woordeboekgebruiker plaasvind wanneer 'n bepaalde woord se betekenisomskrywing gesien of gehoor word.

\subsection{Bevindinge t.o.v. beroepsterme}

Sewe-en-vyftig woorde wat na een of ander beroep verwys se betekenisatome soos wat dit in die leksikale definisie na vore kom, is ontleed (kyk Bylae A). Dit het geblyk dat daar 3 (+VROULIK)-items teenoor 49 (+MANLIK)-items voorkom - 'n ratio van 1:16. Nie een van die vroulike beroepsterme het die kenmerk (+PRESTIGE) besit nie, terwyl 2 die kenmerk (+NEGATIEWE SEKSUELE KONNOTASIE) besit het. Daarteenoor het 19 van die beroepsterme wat die kenmerk (+MANLIK) besit het, ook die kenmerk (+PRESTIGE) vertoon en slegs 1 het die moment (+NEGATIEWE SEKSUELE KONNOTASIE) gehad. Hierdie gegewens sien in tabelvorm soos volg daaruit (Tabel 2): 
Tabel 2

Manlike en vroulike beroepsterme onder die letter M in VAW

Manlik \% van totaal Vroulik \% van totaal

$\begin{array}{lllll}\text { Beroepsterme } & 54 & 95 \% & 3 & 5 \%\end{array}$

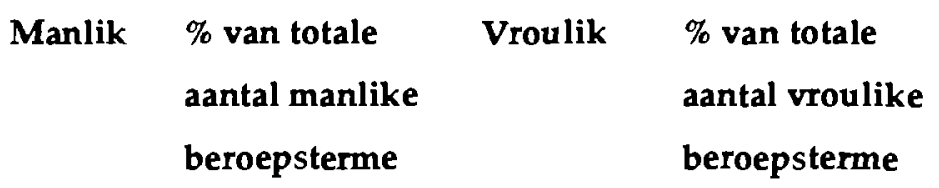

$\begin{array}{lllll}\text { Prestigewoorde } & 21 & 39 \% & 0 & 0 \%\end{array}$

Negatiewe kon-

notasie

$1 \%$

2

$67 \%$

'n Moontlike verklaring vir die voorkoms van relatief min (+VROULIK)-items is die vrou se vroeëre beperkte beroepsgerigtheid, asook haar beperkte mededinging op die meeste beroepsterreine. Aanvanklik het daar dus nie 'n behoefte aan geslagspesifiek-gemerkte vorme bestaan nie.

Liebenberg (1976: 12) sề in dié verband: "... [Olp beroepsgebied is "manlik" dus ongemerk. Waar die vrou sodanige beroepsgebiede betree, word dieselfde benaming in baie gevalle op haar toegepas sonder gebruikmaking van gemerkte (+VROULIK)-morfeme ...". Hierdie toedrag van sake blyk nog steeds die geval te wees. Vergelyk hier:

Sy is 'n makelaar en nie 'n makelares nie.

Vir gebiede waarop sowel 'n man as 'n vrou tradisioneel dieselfde beroep beoefen het, bestaan daar wel aanvaarde terme, naamlik masseur $x$ masseuse; melkjong $x$ melkmeisie; modemaker $x$ modemaakster. 'n Interessante klemverskuiwing in die betekenisleiding kom egter voor by laasgenoemde voorbeeld. 'n Modemaker word aangegee as: "man wat modes ontwerp". 'n Modemaakster, daarenteen, se prestige is heelwat laer, naamlik: "'n vrou wat 
klere vir dames maak, kleremaakster, modiste". Hy ontwerp modes, sy maak klere.

Interessantheidshalwe kan daar ook melding gemaak word van die eienaardigheid wat by die items mitrailleur $x$ mitrailleuse voorkom. Mitrailleur se sinoniemdefinisie lui: "masjiengeweer-skutter"; mitrailleuse daarenteen, se leksikale definisie bestaan slegs uit: "masjiengeweer" - wat hopelik 'n drukfout is!

\subsection{Enkele ander bevindinge}

Die neutraliteit van die manlike vorm blyk uit die feit dat daar onder die letter M 90 woorde met (+MANLIK)-gemerktheid voorkom wat volgens die betekenisbeskrywing op albei geslagte van toepassing is (kyk Bylae B). In al hierdie gevalle is die superordinaat iemand of 'n persoon. ' $n$ Paar gevalle verwys anafories ook spesifiek na 'n manlike subjek terwyl daar slegs in één geval, naamlik medaljewenner, anafories na albei geslagte verwys word. Die geval van die (+MANLIK)-gemerkte vorm, middelspeler, val op. Die leksikale definisie lui soos volg: "speelster in korf- of netbal wat in die middelste posisie op die baan speel". In dié geval beteken manlik, naamlik speler, dus baie duidelik ook vroulik, naamlik speelster.

Onder die letter $M$ is 43 (+MANLIK)-gemerkte woorde gevind (kyk Bylae C) wat, te oordeel na die betekenisleiding wat aangebied word, na albei geslagte verwys sonder dat daar grammatikaal onderskeid getref word.

'n Stereotiepe rolverdeling waarvolgens die manlike geslag 'n aktiewe en die vroulike geslag 'n passiewe rol speel, spreek uit die betekenisverklaring van:

$\begin{array}{ll}\text { maintenée: } & \begin{array}{l}\text { "minnares, houvrou" } \\ \text { mainteneur: }\end{array} \quad \begin{array}{l}\text { "iemand wat 'n maintenée onderhou of aan- } \\ \text { hou" }\end{array}\end{array}$

'n Eensydige rolverwagting spreek ook uit woorde waarvan slegs die vroulike vorm aangegee word, byvoorbeeld: modevertoonster en modiste. Dit is "gepas" vir vroue om met kleremaak en die vertoon daarvan geassosieer te word. Van hulle manlike eweknieë wat net so bedrywig is op diê terrein word daar geen melding gemaak nie.

In enkele gevalle lewer die inligting wat naas die vroulike ekwivalente van sekere lemmas aangebied word, betekenismatig geen bydrae nie. Die vrou word slegs gedefinieer in terme van haar verhouding tot die man. Vergelyk hier: 


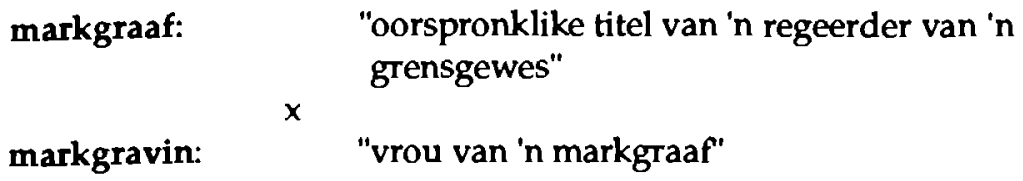

Woorde onder die letter $\mathbf{M}$ waarvan die vroulike en die manlike vorme as aparte lemmas aangegee word, tel slegs 14 (kyk Bylae D). Hieruit blyk dit duidelik dat daar meer plek in die woordeboek aan die manlike geslag afgestaan word en dat die vroulike geslag ook op hierdie wyse "onsigbaar" word. Hier ter sake is dan ook die geval van mansdubbelspel en mansenkelspel wat as twee aparte lemmas opgeteken is terwyl vroue-enkelspel slegs deel uitmaak van die lemma vrouedubbelspel.

Alle komposita in die kategorie (+MENSLIK) wat mede- as eerste lit het - met die uitsondering van 7 (Bylae E) - is genus-neutraal, sodat tensy daar met behulp van die adjektief vroulike gekwalifiseer word dat hulle na die vroulike geslag verwys, die veronderstelling is dat daar na mans verwys word.

Gebruiksleiding wat by die lemma man aangebied word ter toeligting van die betekenisbeskrywing dra nie by tot die betekenis van man nie, maar wel tot manlike stereotipering in die sin dat daar verwys word na: ' $n$ man van aansien; ' $n$ man van die daad; ' $n$ man duisend; ' $n$ man honderd; 'n man van iemand maak; pure man; 'n man van sy woord. Aan positiewe gevoelswaarde gaan die woord man dus duidelik nie mank nie.

Meer in die algemeen is daar gekyk na bevooroordeelde redaksionele kommentaar in leksikale definisies. Die volgende enkele voorbeelde kan dien ter illustrasie:

vrouehater:

mansmens:

vroumens:

mansiek:

vrousiek: "persoon wat die hele vroulike geslag haat; misoginis"

$x$

"vroumens wat (voorgewende) haat koester teenoor mans "

"man; manspersoon"

$x$

"persoon van die vroulike geslag (geringskattend gebruik); kyfagtige vrou"

"gek na mans; oordrewe belangstellend; nimfomaan; 'n mansieke vrou, vrou wat opvallend gek is na mans"

$x$

"byna sieklik geheg aan vroue" 
mannestem/manstem: "stem van 'n man, manstem"

vrouestem:

$\mathbf{x}$

"(kenmerkende) stem van 'n vrou"

In die geheel gesien, kan die volgende afleidings gemaak word:

In soverre dit gebruiksleiding in Tweetalige Woordeboek/Bilingual Dictionary (1984) betref, word daar oorweldigend meer van manlike as van vroulike woorde in voorbeeldsinne gebruik gemaak. Bevooroordeelde kategorisering vind plaas deurdat stereotiepe semantiese assosiasies met manlike en vroulike woorde in verband gebring word.

Betekenisleiding in die Verklarende Afrikaanse Woordeboek (1982) vertoon die volgende kenmerke:

- waar die beroepswêreld ter sprake is, bestaan daar 'n definitiewe neiging om (+MANLIK)-vorme te gebruik om sowel die man as die vrou te benoem;

- die frekwensie van woorde met die (+MANLIK)-vorm wat op albei geslagte van toepassing gemaak word, is opvallend hoog;

woorde wat op 'n geslagspesifieke wyse met bepaalde rolle in verband gebring word, vertoon 'n ongunstige polariteit ten opsigte van die vrou wat tot uiting kom in bevooroordeelde redaksionele kommentaar.

\section{Gevolgtrekking}

In soverre dit die bogenoemde stand van sake betref, moet daar toegegee word dat daar nie sprake is van totale objektiwiteit in die leksikografiese werke wat hier bespreek is nie.

Die opname van gestigmatiseerde woorde in woordeboeke - hetsy ideologiese, rassistiese of seksistiese woorde - is in 'n sekere sin verskoonbaar. Soos Genauer (1976: 15) dit ook in haar proefskrif aandui: "Change is always slow when large groups of people and institutions are involved. So the content of language persists in transmitting stereotypes even when deliberate attempts are made to reduce stereotyping because words carry connotations and auras beyond the control of the speaker or writer." Seksistiese lemmas as sodanig hoef dus nie noodwendig ' $n$ aanduiding van blatante seksisme te wees nie. Wat egter onverskoonbaar is, is betekenis- en gebruiksleiding wat nie die werklikheid weerspieël nie (omdat dit miskien op verouderde, geskrewe bronne berus?) en sodoende voortgaan om die vrou "onsigbaar", en haar nuutverworwe status "onkommunikeerbaar" te maak. 


\section{Verwysings}

Adey, D., M. Orr en D. Swemmer. 1989. Word Power: The South African Handbook of Grammar, Style and Usage. Johannesburg: Ad Donker.

Al-Kasimi, A.M. 1983. Linguistics and Bilingual Dictionaries. Leiden: E.J. Brill.

Allen, J.P.B. en S: Pit Corder (Reds.). 1973. Readings for Applied Linguistics. Londen: Oxford University Press.

Bosman, D.B., I.W. van der Merwe en L.W. Hiemstra. 1984. Tweetalige Woordeboek/Bilingual Dictionary. Kaapstad: Tafelberg.

Botha, T.J.R. (Hoofred.). 1989. Leksikografie en leksikologie. Menlopark: Serva.

Coates, J. en D. Cameron (Reds.). 1988. Women in their Speech Communities: New Perspectioes on Language and Sex. Londen: Longman.

De Roo, E.M. 1990. Taalseksisme in Van Dale: Kort referaat. Tijdschrift voor taalbeheersing 12(1): $40-46$.

Du Plessis, H. en T. du Plessis (Reds.). 1987. Afrikaans en taalpolitiek. Pretoria: HAUM.

Eksteen, L.C. 1967. Die grondslag van gebruik in die verklarende leksikografie. Taalfasette 4: 12-18.

Esterhuyse, J. 1986. Taalapartheid en skoolafrikaans. Emmarentia: Taurus.

Genauer, R.W. 1976. Linguistic Sexism and the Relative Status of Males and Females. Ph.D.-tesis. Case Western Reserve University.

Gershuny, H.L. 1974. Sexist Semantics in the Dictionary. Reoiew of General Semantics 31: 159-169.

Gouws, R.H. 1985. Die omvattende sinchroniese woordeboek as taalkundige handleiding. Referaat gelewer by die SAIVERT-seminaar oor leksikografie, Augustus 1985, Johannesburg.

Gouws, R.H. 1989. Leksikografie. Pretoria: Academica.

Grobler, H. 1983. What is Linguistic Sexism? Communique 8(1): 31-40.

Grobler, H. 1985. Everyday Concepts - Part 1: An Undynamic Lexicographic Process. Communique 10(1): 1-12.

Hauptfleisch, D.C. 1989. Taalseksisme en die woordeboek. Botha, T.J.R. (Hoofred.). 1989: 121128.

Kritzinger, M.S.B. en F.J. Labuschagne. 1982. Verklarende Afrikaanse Woordeboek. Pretoria: J.L. van Schaik.

Liebenberg H. 1976. Genus-onderskeiding in Afrikaans. Taalfasette 21: 1-31.

Lyons, J. 1981. Language and Linguistics. Cambridge: Cambridge University Press.

Spender, D. 1980. Man made Language. Londen: Routledge and Kegan Paul.

Thorne, B. en N. Henley (Reds.). 1975. Language and Sex: Difference and Dominance. Rowley, Massachusetts: Newbury House.

Thorne, B., C. Kramarae en N. Henley (Reds.). 1983. Language, Gender and Society. Rowley, Massachusetts: Newbury House.

Trudgill, P. (Red.). 1978. Sociolinguistic Patterns in British English. Londen: Edward Amold.

Webb, V.N. 1989. Enkele gepolitiseerde woorde in Afrikaans, HAT en die sosiolinguistiek. Botha, T.J.R. (Hoofred.). 1989: 129-142. 
Bylae A

Komponentanalise van beroepsterme

$\begin{array}{llc}\begin{array}{l}\text { Gemeenskaplike } \\ \text { komponent }\end{array} & \begin{array}{l}\text { Diagnostiese } \\ \text { komponent }\end{array} & \begin{array}{c}\text { Supplementêre } \\ \text { komponent }\end{array}\end{array}$

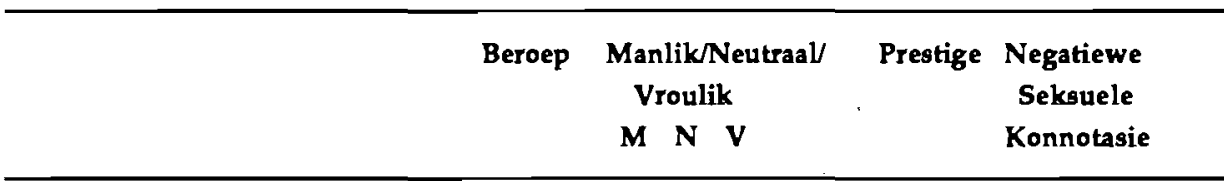

maitresse

malmaakmeisie

markvrou

matroos

Die volgende beroeps-

terme vertoon almal

die kenmerke:

maagdokter, maarskalk,

maestro, magistraat,

majoor, marineoffisier

marinevlieënier, mate-

matikus, medikus,

metafisikus, metroloog,

mikrobioloog, mineraloog,

minister, minister-

president, mioloog munt-

meester, museoloog,

myningenieur, mynkommis-

saris, mynmagnaat

Die volgende beroeps-

terme vertoon almal

die kenmerke:

maatkleremaker, magiër,

magistraatsklerk,

makelaar, mandoor, 
manikuris, manufakturier, marconis, marineskilder, marinier, markmeester, marskramer, masjienmonteur, masjienloods, masjiensetter, masjientekenaar, masjinis, masoreet, medaljeur, meganikus, melkboer, menasiemeester, menasiesoldaat, mesmaker, metaalarbeider, metaalbewerker, metaalgieter, miedpakker, mielieboer, mikroskopis, musikant, mynbass 


\section{Bylae B}

(+ MANLIK)-gemerkte woorde wat op albei geslagte van toepassing is*

"(Superordinaat is telkens "iemand" of "'n persoon")

\begin{tabular}{l} 
maaier \\
maankenner \\
maanreisiger \\
magasynmeester \\
maggewer \\
magnaat \\
máksimalis \\
maler \\
mandjiemaker \\
maner \\
mangelaar \\
maniak \\
maniëris \\
manifestant \\
manipulator \\
manteldraaier \\
marathonloper \\
marionetteur \\
markbederwer \\
marketenter \\
markeur \\
marmerskilder \\
marmerwerker \\
masjienwerker \\
masochis \\
masturbant \\
materiaalberekenaar \\
materialis \\
\hline
\end{tabular}

matrasmaker
matrooskuller
medaljehouer
meedeler
mee-eter
meeloper
megafonis
melancholikus
melkprodusent
menger
meningsvormer
menner
mensdief
mensehater
mensekenner
menshater
merker
messelaar
messlyper
messteker
metaalklopper
metaalwerker
metallurg
metereoloog
meter
meteropnemer
meulenaar
middelaar
mielieafmaker
mikoloog

militaris

minikus

minimalis

misstrooier

mistikus

moddergooier

modelleur

modelmaker

moderator

mokeraar

momskilder

mongool

monomaan

monteur

mooiprater

mooiskrywer

mooiweersvriend

moralis

morfinis

motor bestuurder

motoris

mouter

muisvanger

muntkennèr

muntsnoeier

muntversamelaar

musiekdirekteur

musiekkritikus

musiekresensent

musiekmeester

muurskilder

mylvreter 


\section{Bylae C}

(+ MANLIK)-gemerkte woorde wat klaarblyklik geen vroulike teenharigers het nie

maanbewoner
Macedoniër
mandataris
mandator
Marsbewoner
matador
matspringer
mediateur
medisynmeester
meesterbouer
meesterkneg
meestersanger
melioris
melomaan
memorialis
menseredder
menseter/-vreter
mensevriend
middelman
miljardêr
minnedigter
minnesanger

\author{
misantroop \\ miteskrywer \\ modernis \\ moesjiek \\ momus \\ monogamis \\ monografis \\ monokraat \\ momentalis \\ monopolis \\ monoteiss \\ monseigneur \\ moptapper \\ Mormonis \\ motorbuffe] \\ muezzin \\ mufti \\ muggesifter \\ multimiljoenêr \\ Muselman \\ mylloper /-hardloper
}


18 A.A. Beyleveld en G.J. van Jaarsveld

\section{Bylae D}

Woorde waarvan die manlike en die vroulike vorme as aparte lemmas aangegee word

\begin{tabular}{|c|c|c|}
\hline markgraaf & - & markgravin \\
\hline markies & - & markiesin \\
\hline martelaar & - & martelares \\
\hline masseur & - & masseuse \\
\hline meerman & - & $\begin{array}{l}\text { meermin (sou dit toevallig wees } \\
\text { dat die vroulik van man min is?) }\end{array}$ \\
\hline meester & - & meesteres \\
\hline melkjong & - & melkmeisie \\
\hline minnaar & - & minnares \\
\hline misdadiger & - & misdadigster \\
\hline mitrailleur & - & mitrailleuse \\
\hline modeheertjie & - & modejuffer \\
\hline modemaker & - & modemaakster (hy - ontwerp; sy - maak) \\
\hline moordenaar & - & moordenares \\
\hline mulat & - & mulattin \\
\hline
\end{tabular}




\section{Bylae E}

Genus-neutrale vorme met mede- as bepaler

\begin{tabular}{|c|c|c|c|}
\hline mede- & $\begin{array}{l}\text { aangeklaagde } \\
\text { afgevaardigde } \\
\text { amptenaar } \\
\text { arbeider } \\
\text { begiftigde } \\
\text { belanghebbende } \\
\text { beredderaar } \\
\text { besitter } \\
\text { beskuldigde } \\
\text { bestuurder } \\
\text { bewoner } \\
\text { borg } \\
\text { burgemeester } \\
\text { burger } \\
\text { Christen } \\
\text { dader } \\
\text { deler } \\
\text { dinger } \\
\text { direkteur } \\
\text { eienaar }\end{array}$ & $\begin{array}{l}\text { gas } \\
\text { gedaagde } \\
\text { genoot } \\
\text { geregtigde } \\
\text { getuie } \\
\text { gevangene } \\
\text { helper } \\
\text { hoofbestuurder } \\
\text { huurder } \\
\text { ingesetene } \\
\text { kieser } \\
\text { krygsman } \\
\text { leerling } \\
\text { legataris } \\
\text { leraar } \\
\text { lid } \\
\text { mens } \\
\text { ondergetekende } \\
\text { ondertekenaar } \\
\text { oorlogvoerende }\end{array}$ & $\begin{array}{l}\text { outeur } \\
\text { passasier } \\
\text { pligtige } \\
\text { redakteur } \\
\text { regter } \\
\text { reisiger } \\
\text { skenker } \\
\text { skepsel } \\
\text { skrywer } \\
\text { skuldeiser } \\
\text { skuldenaar } \\
\text { skuldige } \\
\text { stander } \\
\text { stryder } \\
\text { student } \\
\text { verweerder } \\
\text { vlieër }\end{array}$ \\
\hline
\end{tabular}

Woorde met mede- as bepaler waarvan die manlike en die vroulike vorm aangegee word, maar die vroulike vorme nie as aparte lemmas nie

$\begin{array}{llll}\text { mede- } & \text { eksekuteur } & - & \text { eksekutrise } \\ \text { effgenaam } & - & \text { erfgename } \\ \text { minnaar } & - & \text { minnares } \\ \text { stigter } & - & \text { stigteres } \\ \text { voog } & - & \text { voogdes } \\ \text { werker } & - & \text { werkster }\end{array}$

